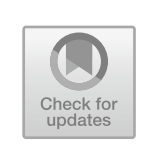

\title{
Historical Memory and Its (Dis)contents
}

\begin{abstract}
Efforts to recover and preserve the historical memory of past violence and injustice are today increasingly widespread in countries wrestling with, or emerging from, violent conflict. This reflects the rise of memory studies as a distinct field of inquiry as well as the growing recognition of the importance of centrally including the voices of victims in the elaboration of narratives of past suffering and evil. However, as an "essentially contested concept," historical memory faces numerous challenges that have to be navigated when conducting applied historical memory work in violence-inflected settings. Among the pitfalls, historical memory work faces the unresolved tension between history and memory, which gives substance to claims that forgetting should trump remembering. Furthermore, owing to it being anchored in the subjective domain of memory, applied historical memory work risks deepening prevailing patterns of hatred, enmity and exclusion, in addition to being instrumentalised and manipulated by hegemonic societal groups and interests. This notwithstanding, the case of Colombia reveals that under certain conditions historical memory work can yield positive results in terms of giving voice to victims on all sides and honouring their entitlement to recover and preserve the memories of past suffering, thereby helping them to address traumatic past experiences.
\end{abstract}

Keywords Historical memory - Narrative - Violent conflict · Victims . Healing · Colombia 
Although a quarter of a century has since passed, I have an unusually vivid recollection of walking into the documentation centre of the Mission of the United Nations in El Salvador (MINUSAL) ${ }^{1}$ and experiencing a deep sensation of awe. It was October of 1997 and I had only just arrived in Central America and my native San Salvador to start the field work for my doctoral thesis on civil-military relations in the aftermath of the armed conflicts that had ravaged El Salvador, Guatemala and Nicaragua (Schultze-Kraft 2001, 2005). Still in the pre-digital age, at least at the United Nations, what I found was an arrangement of library stacks lined with innumerable office binders containing basic data about victims of atrocious crimes and human rights violations committed during a decade of war, mostly by the armed forces of the Salvadorean state but also the insurgent Farabundo Martí National Liberation Front (FMLN in Spanish). ${ }^{2}$ It was as if I had entered a mausoleum where the conflict's estimated 75,000 dead had been laid to rest. This was my first encounter with a meticulous physical record of horrific past events. A novice at the time it left a deep impression on me, though I had no inkling of how

${ }^{1}$ MINUSAL was a remnant of the larger UN Observer Mission in El Salvador (ONUSAL), which was deployed in the country between 1991 and 1995 based on UN Security Council resolution 693 (1991). ONUSAL's mandate was to verify implementation of the agreements between the Government of El Salvador and the insurgent Farabundo Martí National Liberation Front (FMLN in Spanish), including the ceasefire, the reform and reduction of the armed forces, the creation of a new police force, the reform of the judicial and electoral systems, human rights, land tenure and other economic and social issues. See https://peacekeeping.un.org/en/mission/past/onusalmandate.html. Accessed 12 July 2021.

2 The archive I visited in 1997 was built by ONUSAL's human rights staff, not the Truth Commission, which however may have used it. According to the available evidence, after the end of the Truth Commission's work in 1993 its records were sent to the UN Department of Political Affairs, which subsequently handed them over to UN Archives for storage. See https://derechoshumanos.udp.cl/cms/wp-content/uploads/2020/12/ Relatoria_Va_Uses_of_Truth_El_Salvador_TC_archives_access_ENG.pdf. Accessed 13 July 2021. 
to honour and what to do with this silent shrine of human suffering and evil. $^{3}$

Visiting MINUSAL, I had hoped that in addition to the data and information I would gather through in-depth interviews with some of the few remaining national and international staff I would come across narratives of the armed conflict, including the voices of victims and survivors but also those of soldiers, which could help me in the elaboration of my own analysis. That was a naïve hope, which told as much about my early inexperience as an armed conflict researcher as it did about the way in which the thorny subjects of truth and historical clarification were being approached in El Salvador. Unlike other Latin American countries with histories of violent conflict and/or authoritarian state crime, such as Guatemala, Peru, Argentina and Chile, El Salvador has had a more chequered record of dealing with the past violence that beset the small country in the 1980s and early 1990s. Though at the time touted as a model, the UN-sanctioned truth commission in El Salvador, which was headed by three dignitary-experts from Colombia, Venezuela and the United States and had no Salvadorean staff, achieved little more than putting together a comprehensive final report (United Nations Commission on the Truth for El Salvador 1993). However, elaborated over just eight months (July 1992-March 1993), the report was not based on broader outreach to victims and civil society. The implementation of its recommendations by the Salvadorean government, which made it clear that it did not support them, was slow and patchy. A sweeping amnesty for crimes committed prior to 1992 was passed by the Salvadorean legislative assembly a few days after the release of the truth commission's report

3 Since I use the difficult-to-pin-down term "evil" a brief explanatory note is in order. According to David Parkin, one can distinguish between three different senses of the word "evil" as it is typically employed: "the moral, referring to human culpability; the physical, by which is understood destructive elemental forces of nature, for example earthquakes, storms, or the plague; and the metaphysical, by which disorder in the cosmos or in relations with divinity results from a conflict of principles or wills" (Parkin, cited in Csordas 2013: 526). In relation to historical memory and its (dis)contents, which is the subject of this chapter, it is important not to lose sight of evil as both a moral and material or physical category (I am less knowledgeable about evil's metaphysical qualities). Thus understood, evil designates the "the outer limits of the bad" (Pocock, cited in Csordas 2013: 527) in moral and material or physical terms. But it is not the opposite of "good," as in a Manichean conception of good versus evil, which can commonly be found in antagonistic conceptions of, and approaches to, historical memory (Bull and Hansen 2016). 
(Popkin 2000). In hindsight, it seems Salvadorean elites, including the former insurgents, wanted to forget, not remember.

My experience as a young researcher in Central America provided me a first glimpse of the complexities entailed in dealing with violent and traumatic pasts. Since the early post-cold war years, truth commissions have become standard elements of transitional justice efforts and political transitions in many violence-inflected countries around the globe. While such commissions come in different guises, and all have their distinct mandates, they generally are employed to establish an "accurate public record of the past, to give victims some sense of acknowledgement and "closure," to "name and shame" (but not jail or fine) perpetrators, to promote society-wide reflection and reconciliation, and to suggest partial remedies such as reparations for documented victims" (MacCargo 2015: 15). Yet, and not only with respect to El Salvador, there are growing doubts about the effectiveness - and legitimacy — of truth commissions, about their capability to document fully the truth about past atrocities and suffering, about helping violence-ravaged societies to deal with the past, overcome trauma and move towards a state of more peaceful and just coexistence, perhaps even reconciliation (see, for instance, MacCargo 2015; Paulson 2017; Paulson and Bellino 2017).

Against this backdrop, I want to explore an alternative route to truthseeking and historical clarification in violence-inflected countries, namely that of historical memory work. While both standard truth commissions and historical memory initiatives, such as the Colombian one on which I dwell in this chapter, have in common that they are concerned with establishing what happened in the past, they are quite different in the ways they go about their work and what they aim to achieve. Whereas truth commissions are commonly entrusted with establishing who-did-what-to-whom with the goal of contributing to restorative justice, victim reparation and, ultimately, reconciliation, historical memory work is geared more towards generating comprehensive narratives of past violence and injustice based on the memories of those who have suffered it. ${ }^{4}$ Put into interplay with

4 This does not mean, however, that truth commissions and their reports writ large cannot also contribute to promoting what in the South African case has been referred to as "narrative truth." For instance, the work of the truth commissions in Guatemala and Peru served as inputs for initiatives for the recovery and preservation of historical memory among social, indigenous and victim organisations as well as for innovative approaches to history teaching at schools (Laplante 2007; Oglesby 2007). 
the extant historical evidence, such memory narratives are then positioned to unfold deeper meaning and healing power. Historical memory work can therefore be more attuned to long-term processes of healing and helping to overcome trauma by facilitating the emergence of plural, agonistic memories over singular, antagonistic ones (Bull and Hansen 2016). Trying to bring to light as much of the truth about past violence and injustice as possible is of importance in this endeavour. But I would argue it is not the only and foremost goal of historical memory work.

That said, historical memory work is no straightforward and tested undertaking. A great deal depends on the context in which it is conducted and the ways in which it is framed and conducted. Addressing the question of this chapter of what the characteristics and challenges of historical memory work are in countries wrestling with, or emerging from, violent conflict, I start with a brief discussion of the relationship between history and memory. This is followed by a treatment of historical memory as a contested concept and the strengths as well as pitfalls of applied historical memory work. I illustrate my discussion by taking recourse to the impressive, if challenging, state-sanctioned historical memory work that has been conducted in Colombia over the course of the past 15 years.

\subsection{History ANd Memory}

When approaching the subject of historical memory, it is useful to start by looking at its two constituent parts, history and memory, and how they relate- or do not - to one another. Regarding this relationship, it is assumed that history and memory represent distinct forms of knowing about the past, "each purporting ... to connect present consciousness with past reality" (Cubitt 2007: 4). In this vein, memory is typically framed as something "essentially personal and individual," though it is also conceptualised as being "basically connected to social institutions and cultural forms" (Cubitt 2007: 4). From an early age and throughout their lives, human beings remember events and the social and other contexts and constellations in which they unfolded in a past they have known or by different means have come to know of. History, in turn, is conventionally understood as referring to the past writ large, which can be known "as the result of disciplined habits of mind" (Cubitt 2007: 5), that is, particularly through the work of professional historians. Hence, in the case of history, understood both in terms of the past and the efforts of 
academically trained minds to penetrate it and make it known, the relationship between the present viewpoint and past events is believed to be less immediate and personal.

History and memory thus exhibit different phenomenological traits. The former is based on the premise that the past can be approached as a temporally removed object-of infinite dimensions-and is accessible to being examined and made intelligible in the present through the use of rational and objectifying methods of historical inquiry. The latter, by contrast, is better not understood as an object, as the past is in a historical conception, "but (as) a concept, a mental category that we make use of in making sense of complex and elusive aspects of human behaviour and experience (author's emphasis)" (Cubitt 2007: 6). Like the history written by scholars, memory too is concerned with the past. But it cannot be claimed that the act of remembering is principally aimed at uncovering "objective" truths about past events. Such a claim would be missing the point about memory and remembrance. Rather, and that is one of memory's defining traits, individuals and groups engage in remembrance because they know or feel that their present condition of living beings bears witness to something that happened in the past and that can or needs to be dealt with through the mental and/or symbolic act of individual and collective acts of remembering.

Memory therefore operates from the present towards a past confined by the boundaries of felt and lived experience. It seeks to make sense of present conditions through remembering past events from within individuals or social groups, thereby contributing to the formation of both individual and collective identities (see Cubitt 2007). In the realm of academic history, by contrast, the historian approaches the past from her or his particular vantage point as a scholar in the present. Viewing social groups and individuals from the outside, the historian strives to uncover the causalities underlying past developments through the application of rational-objective scientific methods (Cubitt 2007). ${ }^{5}$ Academic history too plays a role in identity formation, but in a more mediated and less immediate fashion by promoting "a sense of transgenerational belonging in which people feel sympathetic connections to other beings from whom they are removed" (Cubitt 2007: 42).

\footnotetext{
5 Though at times historical inquiry is also desireful of illuminating-from a historical vantage point-certain aspects of the present and even the future, it faces significant limitations in successfully conducting such an endeavour (see Hobsbawm 1972).
} 
While it cannot be disputed that in recent decades "memory has become ... a key term in the lexicon of historical study" (Cubitt 2007: 2 ), it is also true that students of history and memory are still nowhere close to reaching a consensus regarding the quality and also the hierarchy of the relationship between these two distinct domains of historical knowledge. Amid the flourishing of memory studies (see, for instance, Cubitt 2007; Rieff 2016; Roediger and Wertsch 2008), it has been suggested that memory cannot serve as a substitute for scientific historical research. Rather, gaining an understanding and elaborating cogent historical interpretations of gone by events must always and necessarily part from the premise that the past is indeed "over." That it represents a temporally distinct and "closed" realm that only trained historians with an expert command of the various methods available to historical research can approach and make intelligible in the present, not transforming and re-signifying it in the process.

In this conception, recourse to memory as a source of historical knowledge is deemed to carry the risk of opening the floodgates to the subjective representation of what in principal ought to be truthful, sharable and verifiable accounts of the past (Cubitt 2007). It is ruled out that the memory of the individual person, who some see as the only possible mnemonic subject, can fulfil these criteria. ${ }^{6}$ While people are capable of reconstructing their individual past through conscious acts of remembrance, in doing so there are no effective checks available that would prevent them from deforming it in the process of remembering (Rieff 2016). If political, social and other collectives were capable of remembering, as is pointed out by scholars who believe that all individual memories are socially conditioned (Bekerman and Zembylas 2012; Cubitt 2007), they could provide such checks on the subjective pitfalls of individual memory and remembrance. However, as long as there is no consensus in the debate about the qualities of individual and the possibility of the existence of collective forms of memory, such as social, historical and cultural memory (Roediger and Wertsch 2008), memory sceptics have it relatively easy to claim that if memory is to be given some room "in investigating occluded truth from the past," then it should also be recognised that "surely it is history that must be the senior partner and memory the junior one" (Rieff 2016: 84).

\footnotetext{
${ }^{6}$ According to one influential advocate of forgetting, "the world does not have memories, nor do nations. Individuals remember, full stop" (Rieff 2016: 54).
} 
The argument in support of academic history is further buttressed by reference to the dangers that have been associated with notions of collective memory, however elusive they may be. Of particular concern in this regard is the fact that efforts to construct collective memories have frequently amounted to strategies of political, ideological and other manipulation (Rieff 2016; Sánchez 2006). In effect, there is no shortage of historical evidence that can be cited showing that collective memory discourses have been appropriated and nurtured by political regimes, states and all manner of social, political and ethnic groups to promote nationalist, exclusionary, authoritarian, racist and other inhumane, antidemocratic and downright evil goals. Just consider cases as diverse as Bosnia-Herzegovina, Colombia, Cyprus, Guatemala, Israel-Palestine, Northern Ireland, Peru and South Africa, where political, military and other elites have gone to great length in the attempt to foster collective memories geared at idealising war and entrenching deep feelings of hatred, vengeance and disrespect vis-à-vis other social and ethnic groups (Bekerman and Zembylas 2012; Hoepken 1999; Rieff 2016; Sánchez 2006, 2019). Invariably, such harmful strategies of memory construction lack-or intentionally ignore-solid historical bases. They reflect the dilemma that "the takeover of history by memory is also the takeover of history by politics" (Rieff 2016: 63).

In other instances, efforts to recover and preserve collective memories may not be tainted in the same way as just described, principally because in these cases it is not the powerful, mighty and disdainful that are driving the memory agenda but the violated and vulnerable who come together in victims' and other types of associations seeking justice, voice and redress for their past suffering. However, even regarding such instances, memory sceptics and/or advocates of forgetting believe that collective memory construction could have harmful side effects. Far from helping to establish the "truth" about past events and enable a society to embark on a positive and constructive forward movement, they are perceived as risks to transitions from authoritarian to democratic rule or from war to peace by insisting too much on the importance of not forgetting past evil and fully holding those responsible to account (Rieff 2016).

The arguments put forward by memory sceptics cannot be dismissed out of hand. As I have shown, such memory discourses are characterised by intellectual, moral and political ambiguities. This notwithstanding, when the critique of memory as a legitimate source of knowledge about past events comes in the guise of a defence of academic history, it 
risks undermining its own foundations. Principally, this is so because the sources that professional historians rely on are in themselves not representations of "objective" historical facts, and therefore cannot be considered to be superior to "subjective" memories. "Historical sources," writes Geoffrey Cubitt, "are not just evidential objects that passively await the historian's critical scrutiny: often, at least, their production and survival reflect earlier efforts either to hold onto elements of a past or present reality that might be in danger of being forgotten, or to influence the retrospective judgements of posterity (author's emphasis)" (Cubitt 2007: 29). This echoes Eric Hobsbawm's observation that the historic past, that is, the past that people in the contemporary world know of through their families and teachers or the works of professional historians and TV programmes, is used to legitimise certain choices and developments in the present. In this process, the creation of useful myths - today some would use the unfortunate term "alt-truths"-is always on the cards and even socially encouraged (Hobsbawm 1972, 1993). Academic historians are $e x$ oficio not immune to these pitfalls for their "approaches to historical study are influenced by what they themselves remember, and memory operates on numerous levels in the transmission of both the information that ends up being encapsulated in historical source materials and of the ideas that shape the way in which these materials are interpreted" (Cubitt 2007: 29).

In my analysis, the struggle for predominance between academic history and individual and/or collective memory work turns ever more contentious as we change the focus from the academic realm of scientific explanation and interpretation of the past to that of lived historical experience under conditions of duress and violations of fundamental rights, including the right to life. It is precisely this change of focus that I believe is necessary to approach the subject of historical memory when it is understood in the terms of an entitlement, not an option or grant, of those who have suffered violence and evil at the hands of others. As I show in the next section, though in itself an ambiguous concept the recovery and preservation of historical memory, such as in Colombia, can in practice contribute to advancing the cause of peace and reconciliation in ways that neither history nor memory on their own would be able to. Yet, if historical memory work is to be effective, much depends on how it is being framed and conducted, and what ultimate ends it is meant to serve. 


\subsection{Historical Memory}

Against the background of the above discussion of the contentious relationship between history and memory, the term historical memory risks coming across as a paradox or tautology of questionable analytical utility. How can memory be or become "historical"? Is memory, understood as a mental category that humans employ to make sense of "complex and elusive aspects of human behaviour and [past] experience" (Cubitt 2007: 6), not always in some way "historical"? How does attaching the modifier "historical" to memory make it any less subjective? Does the term historical memory refer to the memories of individuals as well as collectives? Whose historical memory is being recovered and preserved, and by whom and for what purpose?

Questions like these indicate that we will have to accept that historical memory is what W. B. Gallie calls an "essentially contested concept," that is, a concept "the proper use of which inevitably involves endless disputes about their proper uses on the part of their users" (Gallie 1956: 169). This does not mean, of course, that we should erase the term from our lexicon or that historical memory work cannot be of value. Based on my own experience as a political analyst and outside participant in historical memory processes in Colombia, ${ }^{7}$ which I examine in more detail below, it is. That said, believing in the virtues of historical memory work must not blind us to its challenges and pitfalls in troubled, violence-inflected societies.

Among the positive attributes of historical memory work is the ability to promote individual and collective healing in the aftermath of experiences of trauma (Corredor et al. 2018; Duckworth 2014; Laplante 2007). Traumatic events, such as becoming the victim of physical, sexual and other forms of violence or suffering deracination and diverse types

7 Upon CNMH's invitation, between 2015 and 2018 I participated in the role of speaker and discussant in the second international seminar organised between CNMH and the Colombian War College (Escuela Superior de Guerra) in Bogotá in May 2015 and two subsequent smaller meetings between representatives of CNHM, the Colombian armed forces and members of CNMH's international advisory group, also in Bogotá. Based on this engagement and previous academic work I had done on the Colombian armed forces (Schultze-Kraft 2012), I authored two brief notes on the role of the Colombian military and police in the recovery and preservation of historical memory and its relationship to broader questions of security sector reform in the country (Schultze-Kraft 2016, 2017a). 
of denigration and exclusion, often leave deep traces in the consciousness of persons and communities. Experiences of trauma impact on and transform individual and group identities, potentially up to the point of subduing them or making them disappear altogether. It is against the backdrop of the tremendous effect of traumatic experiences on human identities that historical memory work acquires its significance. "In a deep sense," writes Gonzalo Sánchez, the former CNMH director, "memory is a form of resistance to death, to the disappearance of one's own identity (author's translation)" (Sánchez 2006: 21). Constructing narratives of traumatic events that allow for the conscious acknowledgement and allocation of such events in the realm of memories, which otherwise might remain buried and displaced, enables people and communities to recover a sense of identity and continue with their lives, even achieve positive transformation - forever marked, as they will be, by past trauma. Likewise, listening to the narratives of historical trauma of the "other," who once was the enemy or responsible for the experienced suffering and injustice, is believed to promote social healing and the creation of more peaceful relationships between victims and victimisers. Such relationships are built on the foundations of new identities that make room for the recognition of the "other" as a moral subject and, in the case of the victim, as a subject of rights and autonomous and independent agency (Bekerman and Zembylas 2008, 2012; CNMH 2013; Manojlovic 2018).

Yet the recovery and preservation of historical memory can also have the opposite effects. Ever present in the debate about historical memory is the spectre of the entrenchment of social, ethnic and other antagonisms erected on a "canonical version of history, as well as a Manichean division of the historical characters into good and evil" (Bull and Hansen 2016: 2), risking perpetuating "inherited hatreds" (Sánchez 2006) and "cycles of grief, enmity, and violence" (Duckworth 2014: 171). Regarding Colombia, for instance, Sánchez cautions that in his country,

where the past does not pass because the war does not end, the cult of memory is $[\ldots]$ ambiguous $[\ldots]$ since it can fulfil a liberating function, but it can also produce paralysing effects on the present. [...] In the name of memory $[\ldots]$ the worst crimes have been perpetrated in our national history. Inherited hatreds, by abusing the functions of memory, served for a long time as a trigger for our wars before it was possible to move from revenge to politics (author's translation). (Sánchez 2006: 16) 
Particularly when efforts to recover the memories of past evil and injustice are monopolised by hegemonic social groups and political organisations, and when they are strategically geared towards sustaining the memory of experiences of trauma, especially of trauma that one collective is said to have suffered at the hands of another, they can have profoundly damaging effects. Instead of helping to address trauma and promote healing through critical historical interrogation and the salvaging of victims' memories of resistance and human dignity, such politically and/or ideologically motivated approaches to historical memory work stand to cement societal divisions, promote the intergenerational transmission of trauma and obstruct the formation of new inclusive identities (Duckworth 2014; Zembylas and Bekerman 2008; Manojlovic 2018). Likewise, even when historical memory work is not framed in the way just described but is oriented towards recovering the memories of the victims of violence with the aim of helping them overcome the traumas they have suffered, the result may be that because of the "unknowability and unspeakability associated with traumatic events" victims are inadvertently reduced to a condition in which they are "unable to retell their past and act as agents" (Bull and Hansen 2016). ${ }^{8}$

Here, I want to include a further point that is sometimes overlooked or does not figure prominently in the literature on historical memory and dealing with the past. In settings marked by protracted violence and especially where historical memory work is undertaken amid ongoing violent conflict, such as in Colombia, it ought to be recognised that it will be difficult to establish with any accuracy who has not suffered, who cannot claim to be entitled to some form of social recognition of past trauma, who cannot hope to become dignified in their condition as victim through processes of historical remembering. As a rule, and without wanting in the least to relativise or disown victims' particular condition of vulnerability and victimisers' condition of culpability, it has to be acknowledged that war and violence produce traumatised people all around. This observation supplements the concern expressed by historical memory expert-practitioners that in countries scarred by violent conflict, heinous crimes and massive human rights violations,

${ }^{8}$ Evidently, addressing and seeking to overcome trauma, which I see as a precondition for reconciliation and sustainable peace, does not depend solely on the recovery of historical memories. Other factors, such as political, institutional and other reforms, also play important roles and need to be factored into the equation. 
society has been a victim but also a participant in the confrontation: acquiescence, silence, support and indifference should be a cause for collective reflection. However, this extension of responsibilities to society does not imply the dilution of the concrete and differentiated responsibilities in the triggering and development of the conflict into a "we are all guilty" (author's translation). (CNMH 2013: 16)

Both the omnipresence of trauma, including feelings of cowardice and regret of not having opposed evil-even evil in which one did not have any direct role or stake-and the fact that efforts to recover historical memory are at risk of being hijacked by particular, hegemonic interests and homogenising narratives of the past and its victims, constitute challenges that are difficult to navigate. They reflect the double-edged qualities of historical memory work in countries wrestling with, or emerging from, violent conflict: it can further healing, reconciliation and recovery as much as it can deepen prevailing social, ethnic and other identity-based antagonisms, visceral enmities and historical patterns of exclusion.

\subsection{Historical Memory Work in Colombia}

Preceded by decades of social mobilisation for the defence of human rights and against impunity, during which local historical memory work emerged as a form of resistance to violence exercised by the state and armed non-state groups (Sánchez 2018, 2019), a government-sanctioned initiative to recover and preserve the historical memory of Colombia's protracted armed conflict was launched in 2005. An integral part of Colombia's first-ever transitional justice effort, the creation of the GMH under the umbrella of the National Commission for Reparation and Reconciliation (CNRR in Spanish) reflected a policy paradox (Riaño and Uribe 2016).

On the one hand, the administration of President Álvaro Uribe (20022010) was adamant in denying the existence of an armed conflict in Colombia. According to his government, the violence that was ravaging the country was entirely the work of "narco-terrorists" stopping short of nothing to attack Colombia's legitimate political institutions. Peace negotiations were thus not on the cards. On the other hand, however, the Uribe administration initiated a legislative process that in 2005 resulted in the entry into effect of Law 975 (Gobierno de Colombia 2005). 
This legislation, also known as the Justice and Peace Law, established a framework for the demobilisation and reintegration into civilian life of members of illegal armed groups. It also promoted reconciliation by guaranteeing victims' rights to truth, justice and reparation, including through the recovery and preservation of historical memory, which in the law is stipulated in the terms of an obligation of the state. Consistent with government rhetoric, Law 975 did not explicitly use the term "armed conflict," but it recognised that there were "illegal armed groups" in Colombia, as there were victims who had a right to truth, justice and reparation. The stated overall objective of the legislation was to facilitate peace in Colombia (Gobierno de Colombia 2005).

In practice, Law 975 was applied-with limited effect-to the illegal paramilitary United Self Defence Forces of Colombia (AUC in Spanish) only, not the insurgent FARC and the National Liberation Army (ELN in Spanish). ${ }^{9}$ Unlike in other countries with histories of violent conflict

9 On closer inspection, the policy paradox was not as pronounced as it might appear. Driven by the president's visceral hatred of Colombia's Marxist guerrilla organisations, especially FARC who had killed his landowning father, Uribe certainly saw and depicted the insurgents as "narco-terrorists." It would be difficult to sustain, however, that he applied the same lens to the paramilitaries. Uribe and his people did have an interest in speaking with the AUC, a loose grouping of illegal paramilitary organisations entangled in manifold relationships with political, economic, ecclesiastical and criminal elites as well as elements of the armed forces. In what I have analysed elsewhere as Colombia's hybrid crimilegal order (Schultze-Kraft 2017b, 2018, 2019), there were-and still areclose connections between landed elites and armed groups like the paramilitaries or any of the many successor organisations that sprang up quickly after the AUC's demobilisation between 2003 and 2006 (International Crisis Group 2007). The political problem that Uribe faced right at the start of his first term (2002-2006) was that some of the paramilitary warlords, particularly Carlos Castaño, requested the government help them whitewash and offer them a dignified and safe way out of the depths of crime, depredation and unspeakable violence against innocent civilians. I suggest that Uribe acceded to this request, not least because the paramilitaries were part of his electoral constituency. And he did so by designing and putting to work a two-pronged, perfectly Machiavellian strategy: (a) engaging the paramilitaries in talks about their demobilisation and reintegration on the pretence that they did stick to the unilateral ceasefire they had declared in 2002 and (b) initiating a legislative process geared at producing a law that would grant the paramilitaries, as much as possible, impunity for their heinous crimes and the massive human rights violations they had committed over decades in collusion with members of the armed forces and sectors of Colombia's political and economic elites, especially landed ones. As we know now, the strategy only worked partly. For instance, the government's talks with the paramilitary leadership in Santa Fe de Ralito (Córdoba department) turned out to be chaotic and riven by paramilitary infighting, producing only piecemeal demobilisation deals with the government (Villaraga 2013). For its part, Law 975 underwent 
and mass trauma, such as Argentina, Chile, Guatemala, Peru and South Africa, historical memory work in Colombia has had to deal with the additional challenge of taking place amid ongoing violence, not after the achievement of a conflict settlement. The country's first engagement with transitional justice, including the official mandate for GMH to elaborate a public report on the origins and evolution of the country's illegal armed groups, unfolded at the same time as the armed conflict with FARC and ELN was reaching unprecedented heights.

Composed of a group of respected Colombian anthropologists, historians, lawyers, political scientists, sociologists, social workers and photojournalists (Riaño and Uribe 2016) who oversaw the work conducted by numbers of junior researchers helping with the heavy lifting in the regions, GMH commenced its work in 2007. Enjoying significant operational autonomy and investigative independence vis-à-vis the CNRR and the government, the group defined its mission in the terms of "elaborating an inclusive and integrative narrative, in tune with the voices of the victims, on the origin and evolution of the internal armed conflict in Colombia" (author's translation) (GMH cited in Riaño and Uribe 2017: 16). By legal mandate not a truth commission endowed with executive and judicial powers but called upon to safeguard victims' right to truth and comply with the state's duty of preserving historical memory ${ }^{10}$, GMH dedicated careful consideration to the design of its research and working methodology (CNMH 2013; Riaño and Uribe 2016). Based on a collective and participatory process of consultation and brainstorming, the group resolved to focus its energies on researching and documenting emblematic cases of atrocious crimes and human rights violations.

Aiming at historical clarification not only by establishing who-didwhat-to-whom but also by analysing "illegal armed groups as social and political products of the evolution of [Colombia's] historical configuration" (author's translation) (CNMH 2013: 16), victims' testimonies and narratives of the conflict's impact on their communities and territories

significant-positive-changes during the debates in the Colombian Congress and upon a 2006 ruling of the Constitutional Court that strengthened its provisions with respect to the rights of victims to truth, justice, reparation and non-repetition (International Crisis Group 2006).

10 GMH was established on the basis of Law 975 of 2005. Its successor, CNMH, was created on the basis of Law 1448 of 2011 on victims of the armed conflict and land restitution. Presidential Decree 4803 of 2011 regulates the creation of CNMH as an entity ascribed to the presidency. 
were granted crucial importance. Seeking to build a historical narrative about the conflict that did not pretend to be consensual, and which vehemently distanced itself from institutional patronage and official capture, the generated testimonial evidence was cross-referenced and complemented with data gathered in local and national archives as well as reviews of a broad array of judicial documents, scholarly and grey literatures and mass media sources (CNMH 2013; Riaño and Uribe 2016). In this process, the "historical" character of the recovered memories of violence and injustice was thus meant to be established by confronting individual and collective memories with their locus in the subjective domain, on the one hand, with the "discursive rationality" of history understood as the "evolution of the actual [historical] process (author's translation)" on the other (Sánchez 2006: 14).

The memory work conducted by GMH and its successor organisation, the $\mathrm{CNMH}$, has been nothing short of prolific. ${ }^{11}$ Starting with the 2008 report on the massacre of Trujillo (Valle del Cauca department), by the time the general report ;Basta Ya! Colombia: memorias de guerra $y$ dignidad (CNMH 2013) was released in 2013, ${ }^{12}$ the group had elaborated and published a total of 24 book-length works dealing with emblematic cases of atrocious crimes and human rights violations in different regions of the country and addressing several thematic issues, such as violence against women and forced displacement. Until the change of government in 2018 another 114 reports were released. ${ }^{13}$ This vast body of grounded research has been complemented by a series of films, documentaries and other multimedia products, including podcasts, as well as a range of educational and didactic materials. As mandated by Law 1448 (Gobierno de Colombia 2011a) and Presidential Decree 4803 of 2011 (Gobierno de Colombia 2011b), CNMH also initiated the creation of the Colombian Museum of Memory (Museo de Memoria de Colombia). ${ }^{14}$

${ }^{11}$ For all activities and works published by GMH and $\mathrm{CNHH}$, see the official website https://centrodememoriahistorica.gov.co/. Accessed 12 July 2021.

12 iBasta Ya! can be translated into English as Enough is Enough!

13 Other 21 reports were released between 2019 and 2021 . However, most of these works had been conceived and researched prior to 2019, that is, before Gonzalo Sánchez and his team handed over to the new CNMH director Rubén Acevedo Carmona.

14 The new museum is scheduled to open its doors to the public in 2022. 
Yet, while impressive in its depth, scope and rigour, the efforts of GMH and CNMH were not spared having to deal with the challenges and pitfalls typically associated with the recovery of historical memory in violence-inflected societies. Despite the early decision not to aim for the elaboration of a consensual and common historical narrative but to work on the premise that there is no single and integrated memory of Colombia's violent conflict (CNMH 2013; Riaño and Uribe 2016), in practice it proved challenging to "account for the heterogeneity of local voices $[\ldots]$, or to capture the diverse and differentiated nature of memories of community members" (Riaño and Uribe 2016: 15). Evidently not a homogenous social group, some victims and their representatives took issue with not having been included in the historical memory work or that their voices and memories were underrepresented. ${ }^{15}$ Others, such as the influential Movement of Victims of State Crimes (MOVICE in Spanish), ${ }^{16}$ harboured strong reservations about Law 975, which not without reason they saw as an official scheme to whitewash the paramilitaries and downplay or deny the Colombian state's responsibility in the conflict. This led them to question the overall legitimacy of GMH's work. How could historical clarification and truth about atrocious crimes and massive human rights violations ever be achieved and established, respectively, by an entity sanctioned by the very state that refused to acknowledge of having been at least co-responsible for these crimes, or so the gist of the critique ran (Riaño and Uribe 2016; author's conversation with a leading MOVICE representative in Bogotá after the entry into effect of Law 975). ${ }^{17}$

15 The feeling among some groups of victims of not figuring (sufficiently) in the historical memory accounts produced by GMH also had to do with the research approaches taken by its members. Whereas some were keen to work in highly participatory fashion with victims, consulting a lot among communities and including local researchers in the process, others pursued their work with more of a traditional historiographical focus geared towards testing hypotheses and building scientifically sound narratives (Riaño and Uribe 2016). These differentiated approaches to conducing historical memory work reflect the tensions between history and memory mentioned above.

16 MOVICE is an umbrella organisation of several Colombian victims' associations. Formally established in 2005, one of its most visible members has been Senator Iván Cepeda Castro, son of the leftist Unión Patriótica (UP) congressperson Manuel Cepeda Vargas, whom paramilitaries assassinated in Bogotá in 1994.

17 Here, it is important to note that GMH was acutely aware of the particular discourse and influence of representatives and spokespersons of victims associations who served as mediators in the crucial grassroots work with victims and communities. According to two 
For their part, seizing upon the opportunity offered by the historical memory work to enhance their own political, social and moral capital, liberal urbane elites campaigned for the rights of victims to truth, justice and reparation. However well-intentioned these activities may have been, they contributed to depoliticising "the ways in which the people who had lived through the violence had taken up social struggles for truth and justice, and their stories of political and everyday resistance to the war" (Riaño and Uribe 2016: 18). On a darker note, the perpetrators of atrocities themselves, particularly demobilised paramilitary commanders delivering voluntary confessions in the transitional justice trials, went to great lengths framing their confessions as a gesture of repentance to the victims of their terrible crimes. However, demonstrating repentance and asking for forgiveness was less motivated by a desire to show respect for the victims and their suffering than it was by a cost-benefit calculation of complying with the terms of Law 975 in order to obtain judicial benefits, especially reduced prison sentences (Riaño and Uribe 2016).

Things did not get any easier when, in late 2012, the Colombian War College (Escuela Superior de Guerra) approached CNMH expressing an interest in a module on social research, historical memory and transitional justice that could be incorporated into the study programme and delivered by CNMH staff (CNMH 2018). Cognisant of the involved challenges of working with the military, even if in an educational capacity and under the changed conditions of a new government that had just established peace negotiations with FARC, CNMH remained faithful to its motto "memory is an ally of peace" as well as its mandate stipulated in Law 1448 of 2011 of watching over the rights of all victims of the conflict and acceded to the request (Wills 2019). The module was designed and then taught by CNMH staff throughout 2013. Safe some initial disagreements between the enrolled military officers and the lecturers over parts of the study contents, which were only natural given the contentious nature of historical memory, CNMH's relationship with

GMH members, "the GMH questioned the implications of privileging the accounts of these mediators, who generally were also leading memory initiatives, and the risk that their narratives and explanations would dominate workshops and testimonial spaces" (Riaño and Uribe 2016: 15). This notwithstanding, in order to proceed with the victim-focused memory work GMH did not have much of an alternative but to accept the mediation of these leaders. 
the armed forces reached a low point when its flagship ;Basta Ya! report was officially released in July 2013.

Enraged by President Santos' however diplomatic acknowledgment during the launch ceremony of instances of collusion between state entities and illegal armed groups and of acts of omission on the part of the armed forces, which the iBasta Ya! report details, the tone of the military officers in the classroom turned downright hostile. ${ }^{18}$ Among the grievances voiced by the soldiers was that $\mathrm{CNMH}$ unduly questioned the legitimacy of the Colombian armed forces as a legally established entity of the state that had to be categorically differentiated from the country's illegal—and hence illegitimate-armed groups. Furthermore, the military officers took issue with the sources used by $\mathrm{CNMH}$, which they considered to reflect a leftist ideological bias and therefore could not reveal the truth about the armed conflict. The tense polarisation that had invaded the classroom was exacerbated by a subsequent intervention of the Colombian Ministry of Defence. In an official letter to CNMH, dated 27 December 2013, the ministry reiterated the criticism expressed by the students in uniform, adding to the list of grievances that $\mathrm{CNMH}$ had failed to comply with its legal mandate to work for the dignification of all victims of the conflict because it had not included the soldiers and police that had become victims of international humanitarian law infractions committed by illegal armed groups (CNMH 2018).

In sum, even though after this clash over the construction of the historical memory of Colombia's armed conflict both CNMH and the War College, or at least some of the latter's more yielding representatives, remained committed to finding alternative approaches to their inter-institutional dialogue and resolved to continue with the teaching activities, ${ }^{19}$ it was clear that the "battle for memory" had commenced.

18 Strong criticism of the ¡Basta Ya! report was first expressed by civilian advisors of the Ministry of Defence and retired military officers of the hard-line Colombian Association of Retired Officers of the Armed Forces (ACORE in Spanish) (Wills 2019).

19 In August 2014 and May 2015, CNMH and the War College jointly organised two international seminars on transitional justice and historical memory in Bogotá. Among the participants were Colombian, European, Latin and North American, Asian and African military and police officers and Colombian and international security, human rights and transitional justice experts. In July 2015, the Swiss government facilitated a meeting between representatives of the Colombian armed forces and CNMH in Geneva. Furthermore, taking seriously the grievances voiced by the armed forces about the inclusion of military and police victims of international humanitarian law infractions committed 
And it would not subside again. ${ }^{20}$ With the change of government in 2018, which installed President Iván Duque in power, ${ }^{21}$ Colombia's commendable historical memory work was finally caught up by the hard reality of remembrance being framed not in the terms of breaking through vicious circles of "inherited hatreds" (Sánchez 2006, 2019) but serving as a means to establish, once and for all, the moral superiority of one side and the immoral and criminal nature of the other (Sánchez 2019; Wills 2019). Regardless of the fact that the Colombian armed conflict, just as other contemporary wars, does not fit this Manichean model, the military's hard-line opposition to the ¡Basta Ya! report and CNMH's work overall gradually intermeshed with other powerful interests in a strategy to kill off any efforts at building integrative and plural historical memories granting centrality to the voices of victims. Warning about the spectre of the enthronement of "toxic memories," Sánchez comments on this development,

it would seem that we are moving from the memory of and for the victims to the memory of and for the perpetrators. [...] The memory of the victims is remaining as a shadow between the saviour's memory of the paramilitaries and the heroic memory of the military (author's translation). (Sánchez 2019: 22)

Yet despite the challenges encountered along the way, the available evidence suggests that rather than drawbacks they reflect GMH's and

by illegal armed groups, such as personnel who sustained life-changing injuries in antipersonnel mine incidents, through the Unit for the Attention and Integral Reparation to the Victims of the Armed Conflict, an entity created in 2012 and ascribed to the presidency, CNMH established a dialogue with regional military units (CNMH 2018; Wills 2019). Among the achievements of this new line of historical memory work is the report Esa mina llevaba mi nombre, published in 2016 (CNMH 2016).

${ }^{20}$ For instance, years after the first altercation surrounding the publication of the iBasta Ya! report, in a meeting sponsored by the Swiss embassy in Bogotá in October 2016 security sector representatives reiterated the same grievances that had been expressed in 2013 and even requested CNMH to produce an updated version of the report addressing their concerns. Supported by the Swiss and the International Organisation for Migration (OIM in Spanish), CNMH declined to engage with this request (Wills 2019).

21 Succeeding President Santos (2010-2018), who negotiated with FARC, achieved the 2016 peace agreement with the insurgents and supported the ongoing historical memory work, President Iván Duque (2018 to present) has shown much less commitment to both the implementation of the provisions in the peace accord and independent and autonomous historical memory work. 
CNMH's effectiveness at generating and making widely accessible a novel narrative of the Colombian armed conflict based on hitherto unexplored forms of conducting grounded research that centrally incorporated the voices of victims (Riaño and Uribe 2016). In this respect, it is telling and uplifting that the communities across the country that figure in the historical memory works produced together with GMH and $\mathrm{CNMH}$ have shown the most interest in this resilient effort of historical clarification. While this "exemplifies the merits and dilemmas facing historical memory work that seeks to be inclusive of the voices of the victims in the midst of war" (Riaño and Uribe 2016: 18), it is also true that for the first time in Colombian history pivotal state entities, such as the military (SchultzeKraft 2012), and other powerful organisations and groups in society, including in the private sector and among the well-to-do, could not easily look the other way. The work conducted by GMH and $\mathrm{CNMH}$ has compelled them to take note of the viciousness of a violent conflict that for more than half a century has been destroying the lives and denying the fundamental rights of countless of their less fortunate and privileged fellow citizens.

In light of these achievements, it is a rhetorical question to ask whether promoting forgetfulness would have been a better alternative. There are many insights and lessons, both positive and negative, that can be drawn from the Colombian endeavour to recover and preserve the historical memory of the armed conflict under conditions of ongoing violence. Whether in the longer run these efforts, alongside those that have been undertaken in the framework of the peace negotiations between the Santos administration and FARC leading to the 2016 peace accord and endowing the issue of historical memory with significance for broader sectors of Colombian society, will contribute to transforming the country into a less violence-inflected and more equitable and peaceful society and political entity remains to be seen. Much more work than I can offer here is needed to examine the Colombian experience and compare it to other instances of historical clarification of violent conflict through the recovery of historical memory across the globe. This notwithstanding, the time is ripe to re-energise the pursuit of pathways to employing historical memory work in the classroom, both as a means and an end to building and sustaining peace in troubled societies. The next chapter addresses these issues. 


\section{REFERENCES}

Bekerman, Zvi, and Michalinos Zembylas. "Education and the dangerous memories of historical trauma: Narratives of pain, narratives of hope." Curriculum Inquiry 38, no. 2 (2008): 125-154.

Bekerman, Zvi, and Michalinos Zembylas. Teaching Contested Narratives. Identity, Memory and Reconciliation in Peace Education and Beyond. Cambridge: Cambridge University Press, 2012.

Bull, Anna, and Hans Hansen. "On agonistic memory." Memory Studies 9, no. 4 (2016): 390-404.

Centro Nacional de Memoria Histórica (CNMH). ;Basta Ya! Colombia: Memorias de guerra y dignidad. Bogotá: $\mathrm{CNMH}, 2013$.

Centro Nacional de Memoria Histórica (CNMH). Esa mina llevaba mi nombre. Bogotá: CNMH, 2016.

Centro Nacional de Memoria Histórica (CNMH). Conversaciones inéditas entre la Fuerza Pública y el Centro Nacional de Memoria Histórica: aprendizajes de una experiencia (2012-2017). Bogotá: CNMH, 2018.

Comisión Nacional de Reparación y Reconciliación (CNRR). Trujillo. Una tragedia que no cesa. Bogotá: Planeta, 2008.

Corredor, Javier, Maria Emma Wills, and Mikel Asensio-Brouard. "Historical memory education for peace and justice: definition of a field." Journal of Peace Education 15, no. 2 (2018): 169-190. https://doi.org/10.1080/174 00201.2018.1463208.

Csordas, Thomas. "Morality as a cultural system?" Current Anthropology 54, no. 5 (2013): 523-546.

Cubitt, Geoffrey. History and Memory. Manchester: Manchester University Press, 2007.

Duckworth, Cheryl. "History, memory, and peace education: History's hardest questions in the classroom." Peace \& Change 40, vol. 2 (2014): 167-193.

Gallie, W. B. "Essentially Contested Concepts." Proceedings of the Aristotelian Society, New Series 56 (1956): 167-198.

Gobierno de Colombia. "Ley 975 de 2005 (julio 25)." Diario Oficial (2005). Accessed 10 June 2020: http://www.secretariasenado.gov.co/senado/bas edoc/ley_0975_2005.html

Gobierno de Colombia. "Ley 1448 de 2011 (junio 10)." Diario Oficial (2011a). Accessed 10 June 2020: http://wp.presidencia.gov.co/sitios/nor mativa/leyes/Documents/Juridica/LEY\%201448\%20DE\%202011.pdf

Gobierno de Colombia. "Decreto 4803 de 2011. Por el cual se establece la estructura del Centro de Memoria Histórica." Diario Oficial (20 de diciembre) (2011b). Accessed 30 October 2021: https://vlex.com.co/vid/ decreto-353524850. 
Gobierno de Colombia. "Ley 1732 de 2014 (septiembre 01)." Diario Oficial (2014). Accessed 4 June 2020: http://www.suin-juriscol.gov.co/viewDocum ent.asp?ruta=Leyes $/ 1687408$.

Gobierno de Colombia. "Decreto 1038 de 2015 (mayo 25)." Diario Oficial (2015). Accessed 29 May 2020: http://www.suin-juriscol.gov.co/viewDo cument.asp?ruta=Decretos $/ 30019815$.

Hobsbawm, Eric. "The social function of the past: Some questions." Past and Present 55, no. l (1972): 3-17. https://doi.org/10.1093/past/55.1.3.

Hobsbawm, Eric. "The New Threat to History." New York Review of Books, 16 December (1993): 62-65.

Hoepken, Wolfgang. "War, memory, and education in a fragmented society: The case of Yugoslavia." East European Politics and Societies 13, no. 1 (1999): 190-227.

International Crisis Group. Colombia: Towards Peace and Justice? Latin America Report 16. Bogotá/Brussels: International Crisis Group, 14 March 2006.

International Crisis Group. Colombia's New Armed Groups. Latin America Report 20. Bogotá/Brussels: International Crisis Group, 10 May 2007.

Laplante, Lisa. "The Peruvian Truth Commission's historical memory project: Empowering truth-tellers to confront truth deniers." Journal of Human Rights 6, no. 4 (2007): 433-452. https://doi.org/10.1080/147548307016 92989.

MacCargo, Duncan. "Transitional justice and its discontents." Journal of Democracy 26, no. 2 (2015): 5-20.

Manojlovic, Borislava. Education for Sustainable Peace and Conflict Resilient Communities Cham: Palgrave Macmillan, 2018.

Oglesby, Elisabeth. Educating citizens in Postwar Guatemala: Historical memory, genocide, and the culture of peace. Radical History Review 97 (2007): 77-98. https://doi.org/10.1215/01636545-2006-013.

Paulson, Julia. "From truth to textbook: The Peruvian Truth and Reconciliation Commission, educational resources and the challenges of teaching about recent conflict." In (Re)constructing Memory: Education, Identity, and Conflict, edited by Michelle Bellino and James Williams, 291-311. Rotterdam: Sense Publishers, 2017.

Paulson, Julia, and Michelle Bellino. "Truth commissions, education, and positive peace: An analysis of truth commission final reports (1980-2015)." Comparative Education 53, no. 3 (2017): 351-378. https://doi.org/10.1080/030 50068.2017.1334428.

Popkin, Margaret. Peace Without Justice. Obstacles to Building the Rule of Law in El Salvador. University Park, PA: The Pennsylvania University Press, 2000.

Riaño, Pilar, and María Victoria Uribe. "Construyendo memoria en medio del conflicto: el Grupo de Memoria Histórica de Colombia." Revista de Estudios Colombianos 50 (2017): 9-23. 
Riaño, Pilar, and María Victoria Uribe. "Constructing Memory Amidst War: The Historical Memory Group of Colombia." International Journal of Transitional Justice 10, no. 1 (2016): 6-24. https://doi.org/10.1093/ijtj/ ijv036.

Rieff, David. In Praise of Forgetting. Historical Memory and Its Ironies. New Haven and London: Yale University Press, 2016.

Roediger, Henry, and James Wertsch. "Creating a new discipline of memory studies." Memory Studies 1, no. 1 (2008): 9-22.

Sánchez, Gonzalo. Guerras, memoria e historia. Bogotá: La Carreta Histórica, 2006.

Sánchez, Gonzalo. "Reflexiones sobre genealogía y políticas de la memoria en Colombia." Análisis Político 92 (2018): 96-114.

Sánchez, Gonzalo. Memorias, subjetividades y politica. Ensayos sobre un pais que se niega a dejar la guerra. Bogotá: Editorial Planeta Colombiana S.A., 2019.

Schultze-Kraft, Markus. The Quest for Democratic Civility: Pacification and CivilMilitary Relations in Post-conflict Central America. PhD thesis, University of Oxford Social Science Division, 2001.

Schultze-Kraft, Markus. Pacificación y poder civil en Centroamérica. Las relaciones civico-militares en El Salvador, Guatemala y Nicaragua en el posconflicto. Bogotá: Editorial Norma, 2005.

Schultze-Kraft, Markus. "La cuestión militar en Colombia: la fuerza pública y los retos de la construcción de la paz." In Construcción de paz en Colombia, edited by Angelika Rettberg, 405-433. Bogotá: Universidad de los Andes, 2012.

Schultze-Kraft, Markus. "Memoria histórica: clave para la reforma del sector seguridad y la construcción de paz." Le Monde Diplomatique Colombia 152 (February 2016) (2016), 4-5. Accessed 12 July 2021: https://www.desdeabajo.info/colombia/item/28203-memoria-histor ica-clave-para-reforma-del-sector-seguridad-y-construccion-de-paz.html.

Schultze-Kraft, Markus. Colombia's Quest for Historic Memory and Peacebuilding. London: Oxford Research Group, 2017 (2017a).

Schultze-Kraft, Markus. "Friedensschaffung durch Entflechtung von Herrschaftsordnung und organisierter Kriminalität? - Ein Deutungsversuch des kolumbianischen Friedensprozesses unter Anwendung des Konzepts der krimilegalen Aushandlung." Monatsschrift für Kriminologie und Strafrechtsreform 100, no. 5 (2017) (2017b): 344-359. https://doi.org/10.1515/mkr-20171000504.

Schultze-Kraft, Markus. "Making peace in seas of crime: Crimilegal order and armed conflict termination in Colombia." Crime, Law and Social Change 69, no. 4 (2018): 475-496. https://doi.org/10.1007/s10611-017-9759-2. 
Schultze-Kraft, Markus. Crimilegal Orders, Governance and Armed Conflict. Cham: Palgrave Macmillan, 2019. https://doi.org/10.1007/978-3-030-034 42-9.

United Nations Commission on the Truth for El Salvador. From Madness to Hope. The 12-Year War in El Salvador. New York: United Nations, 15 March 1993. Accessed 12 July 2021: http://www.derechos.org/nizkor/salvador/inf ormes/truth.html.

Villaraga, Álvaro. "Acuerdos de desmovilización, desarme y reinserción con las AUC. Desmovilización parcial, reintegración afectada por reincidencias y rearmes y pervivencia del fenómeno paramilitar." In Tomo VI: El Gobierno Uribe frente al conflicto armado y la paz, acuerdo con las AUC, edited by Álvaro Villaraga, 67-103. Bogotá: Fundación Cultura Democrática, 2013.

Wills, María Emma. "Vicisitudes de una experiencia inédita: La relación entre Fuerza Pública y el Centro Nacional de Memoria Histórica en Colombia." Unpublished typescript, 2019.

Open Access This chapter is licensed under the terms of the Creative Commons Attribution 4.0 International License (http://creativecommons.org/licenses/ by $/ 4.0 /)$, which permits use, sharing, adaptation, distribution and reproduction in any medium or format, as long as you give appropriate credit to the original author(s) and the source, provide a link to the Creative Commons license and indicate if changes were made.

The images or other third party material in this chapter are included in the chapter's Creative Commons license, unless indicated otherwise in a credit line to the material. If material is not included in the chapter's Creative Commons license and your intended use is not permitted by statutory regulation or exceeds the permitted use, you will need to obtain permission directly from the copyright holder.

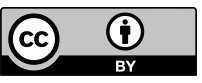

